\title{
Phenomenon and determinant characteristics of NEET (Not in Employment, Education or Training) youth in matrilineal province
}

\author{
Chintia Anggraini ${ }^{1 *}$; Werry Darta Taifur ${ }^{2}$; Zulkifli N. ${ }^{3}$ \\ 1), 2), 3) Faculty of Economics, Universitas Andalas, Indonesia \\ *To whom correspondence should be addressed. Email: chintia@bps.go.id
}

\begin{abstract}
Economic development positions human as an important factor of production. Therefore quality human resources are needed for sustainable development. Indonesia as a country with a large population potential is expected to take advantage of the opportunity through demographic bonuses that will occur in 2020-2030. However, the emergence of NEET (not in employment, education or training) has become a new problem that threatens the success of development. NEET is a measure that includes young people in the age range of 15-24 years old, who are not in employment, education or training. NEET is considered more comprehensive than unemployment because it can see the dynamics and activeness of youth in the labor market. The presence of NEET is inseparable from the determinant characteristics the chances of someone becoming a NEET youth. This study uses Sakernas data for 2017 and 2018 to see the phenomenon and determinant characteristics of NEET status. The result showed NEET youth in West Sumatera was dominated by economically inactive youth. And by using logistic regression analysis, obtained several characteristic that significantly influence the chance of youth's vulnerability to become a NEET. Youth who live in rural areas have a greater opportunity to become NEET youth, while youth with high level education are even more vulnerable to becoming NEET. Gender does not have a significant effect on determinants of NEET status in areas that adhere to this matrilineal kinship system. Based on the result of this study, the government as the holder of authority is expected to implement policies to reduce the proportion of NEET youth.
\end{abstract}

Keyword: Education, NEET, Training, Unemployment, Youth

JEL Classification: I25, J13, J64, O15

\section{INTRODUCTION}

Human resources are the most important part in the development of a country. Abundant natural wealth and capital will not provide the maximum contribution as long as it is not supported by adequate human resources. Siregar (2017) states that the acceleration of the economic development level can be obtained by utilizing superior human resources. In addition, according to Lee (2018), effort to improve the quality of human resources are important of sustainable growth, because it provides opportunity for middle-income economies to move to high-income economies. This confirms that improving the quality of human resources has the opportunity to increase people's income, so that in general it will have a positive influence on improving the economy of a region. 
Quality human resources cannot be obtained easily. Improving the quality of human resources is a long-term investment activity because the quality of human resources in the future is inseparable from investment made at this time. According to Schultz (1961) education and training is a form of human resource investment activities. Education is one of the pulleys in increasing future income. Furthermore, Schultz (1961) states that investment made in education will affect the increase in income. In addition, Mincer (1974) shows that besides the work experience, the length of education also determines the income received by workers. Not only education, job training is also one form of effort to increase productivity. Job training can be done by someone at the time before looking for work or already in a job. Becker (1994) states that training conducted at work is an important form of investment because it will affect income. Increased productivity gained through training will have an impact on future income increases, although at the same time of training the will be an increase in spending to finance job training.

Indonesia as a country with large population is expected to make improvements continuously related to the quality of human resources. Based on data from the National Bureau of Statistics (2019) the population of Indonesia in 2018 reached 265.015 million with 131.005 million workforce, of which 20,830 million (15.90 percent) were young people (15-24 years old). This is a fantastic amount that can be basic capital in the implementation of development in Indonesia. Besides that, the demographic transition in the last few decades, Indonesia is expected to enjoy a demographic bonus in the period 2020-2030 (Maryati, 2015). Demographic bonus is a condition where the productive population exceeds the nonproductive population. Specifically for the province of West Sumatera, according to BPS (2012) the phenomenon of demographic bonus is expected to occur in 2025, where the dependency burden figure which illustrates the ratio of nonproductive population to productive population is at the lowest value of 50.07 percent.

The emergence issues related to NEET youth in various countries in the world becomes a new challenge in preparing reliable resources for the future. NEET (not in employment, education or training) is a measure that includes young people in the age range of 15 to 24 years old, who are not in employment, not in the education system and not in job training (BPS, 2017). Given the understanding of NEET, the existence of NEET is feared to be threat to demographic bonuses in Indonesia. NEET youth who are supposed to get education or training (15-24 years old) or get a job (19-24 years old), are actually in a state that is contrary to their ideal condition. NEET is relatively new and more comprehensive indicator for analyzing the difficulties of labor market and dropping out of school in youth and measuring the level of youth activity (Crismaru, Gagauz, \& Buciuceanu-Vrabie, 2017). Moreover, the NEET concept can be used to capture the dynamics of labor market and provide a complete circumstance of the quality and productivity of work (International Labour Organization, 2017). Additionally according to Furlong (2006) the reason for placing NEET as an important concept in policy making is related to the effectiveness of NEET in predicting the NEET youth future vulnerability to become unemployed in the future.

The presence of NEET youth will have an impact on economic and social life of the community. NEET youth will be a burden on those who work and become a burden in the economy in general. This in line with report of Understanding Children's Work (2013) which states that NEET youths are productive age population who are not used so that they will become obstacles to the economy of a country at the macro level. Furthermore NEET also has an impact on increasing poverty (Bălan, 2016). Poverty 
caused not only results in an increase poverty of NEET youth family, but also contributes to an increase poverty in an area. Another negative impact that can be caused is that NEET youth will be more vulnerable to depression and exclusion in social life (Statistics Canada, 2018). In addition, there are as many 30-35 percent of young criminal who are NEET youth, with a higher proportion of male youth involvement than female (Young Women's Trust, 2014).

The NEET phenomenon in various countries has made it an issue that needs serious attention. Drakaki, Papadakis, Kyridis, \& Papargyris (2014) related to their research stated that the emergence of NEET youth in Greece was the impact of the economic downturn in the country. Meanwhile, Byoung-hoon \& Jong-sung (2012) found the emergence of NEET youth triggered by macro and micro factors. Macro dimension of labor demand is the main factor influencing the emergence of inactive youth. While unemployment is more influenced by more complex factors, namely economic growth, population structure, education system, and labor market conditions. While the micro factors that influence the emergence of NEET youth include gender, education and family income.

Susanli (2016) found that age, gender, marital status, residential area and number of family members influence the presence of NEET in Turkey. And it was found the proportion of NEET youth in this country reached 27 percent at 2013. Alfieri, Sironi, Marta, Rosina\& Marzana (2015) stated that the education level of parents influences the emergence of NEET youth in Italy. Meanwhile Inui, Sano, \& Hiratsuka (2015) found that youth in the transition period had a greater risk of entering NEET status. So, the tendency of youth become NEET is influenced by age, gender, educational background, region and family background.

Indonesia became the country with the highest NEET proportion in Southeast Asia in 2016, with a proportion reaching 23.3 percent (International Labour Organization, 2017). This relatively high number is a challenge for the government and the community to be able working together in dealing the problems that arise due to the presence of NEET youth. And also continue trying to reduce the number and proportion of NEET youth. As stated in the Sustainable Development Goals (SDGs) on the $8^{\text {th }}$ goal, which is to substantially reduce the proportion of young people who are unemployment, without education or training (NEET) (BPS, 2016).

West Sumatera is the only province in Indonesia that adopts a matrilineal kinship system. Matrilineal kinship is arranged according to maternal lineage which places women in special and respectable positions. According to Hakimi (1976) the privileges of Minangkabau women are descendants based on maternal lineage, women as home owner, economic resources or prioritized for women, economic result are kept by women and women also have the right in consultation. Women in West Sumatera are given the freedom to be able to take part in the public sphere without leaving obligation in the household. Regarding NEET youth issues, young women in West Sumatera are required to play their roles as women in matrilineal kinship positions and women's position in the labor market. The proportion of NEET youth in West Sumatera province in 2017 reached 18.27 percent and experienced an increase in 2018 to 20.28 percent (BPS, 2019). This increase implies the need for more serious handling by the government and the community, so that the proportion and number of NEET youth can be reduced for the following years.

Based on the increasing proportion of NEET youth in West Sumatera province and the lack of research and literature related to NEET youth in this region, this study is intended to examine the phenomenon and characteristics that determine the opportunity 
of a youth entering into NEET status in a province that adheres to this matrilineal kinship system.

\section{METHODS}

This study uses raw data from the National Labor Force Survey (Sakernas) in August 2017 and 2018 from the National Bureau of Statistics (BPS) of West Sumatera province. The research unit is individual aged 15-24 years old, spread across 19 regencies/ municipalities in West Sumatera province. There were 4,133 respondents in 2017 and 3,686 respondents in 2018.

The data analysis method used is logistic regression analysis. This analysis aims to determine the opportunities of youth categorized into NEET based on the characteristics used. Youth status in the form of categorical data becomes dependent variable $\mathrm{Y}$, while the defining characteristic referred are independent variable $\mathrm{X}$.

\section{Logistic regression model}

The model used refers to the logistic regression model according to Hosmer \& Lemeshow (1989). The basic regression logistic model used to estimated the determinant characteristic of youth opportunities to become NEET in West Sumatera province can be written as:

$$
Y=\ln \left(\frac{p}{1-p}\right)=\beta_{0}+\beta_{1} \operatorname{Reg}+\beta_{2} \text { Gend }+\beta_{3} M a r+\beta_{4} E d u+\beta_{5} M a r_{-} H H+
$$

Where $\left(\frac{p}{1-p}\right)$ is the probability of youth (15-24 years old) categorized as NEET, $\beta_{0}$ is a constant, $\beta_{1}-\beta_{6}$ are regression coefficients, Reg is a the regional classifications of youth residential areas, Gend is the gender of youth, Mar is the marital status of youth, $E d u$ is the education level of youth, $\mathrm{Mar}_{-} \mathrm{HH}$ is the marital status of household head, and $E d u_{-} H H$ is the education level of household head. Model (1) is said to be the basic model because later the other model obtained must go through several types of tests, so that a regression model that can contain all the characteristics is a model that is less feasible to use.

\section{Odds ratio}

The odds ratio illustrates the interpretation of the logistic regression coefficient to see the extent of the real effect of the independent variable. The odds ratio is obtained by comparing the odds value of one of the variable values with the odds value of the variable being the reference. If there are two categories used for example 0 and 1,0 as a reference, then the odds ratio value for category 1 is expressed as follows:

$\varphi=\left[\frac{p\left(X_{j}=1\right) /\left(1-p\left(X_{j}=1\right)\right)}{p\left(X_{j}=0\right) /\left(1-p\left(X_{j}=0\right)\right)}\right]=\exp \left(\beta_{j}\right)$

The result of $\exp \left(\beta_{j}\right)$ is the value of odds ratio for each independent variable.

There are several stages of testing the logistic regression model. According to Hosmer \& Lemeshow (1989) the stages of testing in logistic regression are as follows:

\section{Testing the significance of the model overall (overall fit test)}

This test is intended to check whether the independent variables together have a real effect in the model. The test statistic used in the G-test can be written as:

$G=-2 \ln \left[\frac{\text { Likeli } \square \text { oodwit } \square \text { outindependentvariabel }}{\text { Likeli } \square \text { oodwit } \square \text { independentvariables }}\right]$ 
The hypothesis in this test is:

$\mathrm{H}_{0}: \beta_{1}=\beta_{2}=\cdots=\beta_{k}=0$; there is no effect of all independent variables on the dependent variable

$\mathrm{H}_{1}$ : there is $\beta_{j} \neq 0 ; j=1,2, \ldots, k$; there is effect of independent variable at least one independent variable on the dependent variable

Test criteria: $\mathrm{H}_{0}$ is rejected if the value of $\mathrm{G}>\chi_{\alpha, k}^{2}$ or the significance value $<\alpha$.

\section{Partial test of parameters significance (partial test)}

This test used to see the real effect of parameters on model separately. The test statistic used is the Wald-test, which can be write as:

$W_{j}=\left(\frac{\beta_{j}}{S E\left(\beta_{j}\right)}\right)^{2} ; \mathrm{j}=0,1,2, \ldots, \mathrm{k}$

Where $S E\left(\beta_{j}\right)$ is standard error of $\beta_{j}$.

The hypothesis used is:

$\mathrm{H}_{0}: \beta_{j}=0$; the independent variable does not significantly affect the dependent variable

$\mathrm{H}_{1}: \beta_{j} \neq 0 ; j=1,2 \ldots, k$; the independent variable significantly affect the dependent variable

Test criteria: $\mathrm{H}_{0}$ is rejected if the value of $\mathrm{W}>\chi_{\alpha, 1}^{2}$ or the significance value $<\alpha$.

\section{Model compatibility test (goodness of fit)}

Model compatibility test (Goodness of Fit) is performed to see the suitability of the model with the data used. The test statistic used is the Hosmer-Lemeshow test, namely:

$\hat{C}=\sum_{i=1}^{g} \frac{\left(O_{i}-N_{i} \overline{\pi_{l}}\right)^{2}}{N_{i} \overline{\pi_{l}}\left(1-\overline{\pi_{l}}\right)}$

Where $N_{i}$ is the total observation frequency of the $\mathrm{i}^{\text {th }}$ group, $O_{i}$ is the observation frequency of the $\mathrm{i}^{\text {th }}$ group and $\bar{\pi}_{l}$ is the average estimated opportunity of the $\mathrm{i}^{\text {th }}$ group.

The hypothesis used is:

$\mathrm{H}_{0}$ : the model is quite capable of explaining data

$\mathrm{H}_{1}$ : the model is not enough to explain the data

Test criteria: $\mathrm{H}_{0}$ is rejected if the value of $\hat{C}>\chi_{\alpha, g-2}^{2}$ or the significance value $<\alpha$.

\section{RESULTS AND DISCUSSION}

\section{Proportion of NEET youth by regency and municipality}

Figure 1 shows the proportion of NEET youth in regency and municipality in West Sumatera province based on the sample used. There are 12 regencies and 7 municipalities in West Sumatera. In the two years in a row, Bukittinggi municipality became the region with the lowest proportion of NEET youth, while Pasaman district was the region with the highest proportion. The proportion of NEET youth in Bukittinggi municipality is 11.17 percent in 2017 and 11.32 percent in 2018. Meanwhile, the proportion of NEET youth in Pasaman district is 28.04 percent in 2017 and has increased to 30.60 percent in 2018. 


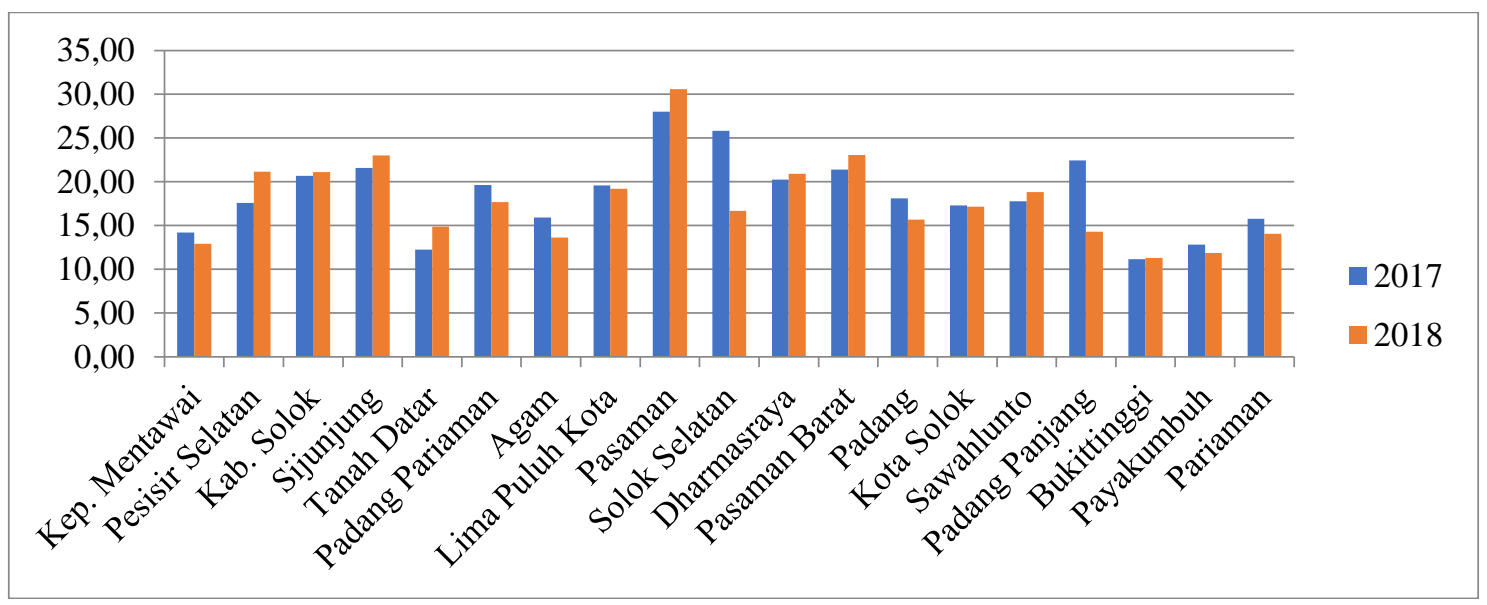

Figure 1. Proportion of NEET youth by regency/ municipality in West Sumatera Province in 2017 and 2018

The magnitude of NEET youth proportion provides quite varied values between regencies and municipalities in West Sumatera (for more clearly see Appendix). In the regency area, the proportion of NEET youth in 2017 ranged from 12.25 percent in Tanah Datar district to 28.04 percent in Pasaman district, and was in range of 12.90 percent in Mentawai Islands district to 30.60 percent in Pasaman district in 2018. There are has been an increase the proportion of NEET youth in the regency area in the last two years. As for the municipality area, in 2017 the proportion of NEET youth is in the range of 11.17 percent in Bukittinggi municipality to 22.45 percent at Padang Panjang municipality. And in 2018 it is in range of 11.32 percent in Bukittinggi municipality to 18.84 percent in Sawahlunto municipality.

The value of NEET youth proportion shows that the proportion of NEET youth in the regency area is relatively higher compared to the municipality area. This relates to the classification of rural and urban areas. In the regency area there are more areas with rural classification. Susanli (2016) states that youth who lives in rural areas tend to be easier becoming NEET status compared to youth who live in urban areas. So, it is not surprising that the proportion of NEET youth is higher in the regency area compared to the municipality area in West Sumatera province.

\section{NEET youth activity levels}

The level of NEET youth activeness illustrated youth activity in finding work. There are two categories of NEET youth activity levels, namely active and not actively seeking work. Actively looking for work is defined as unemployment whereas those who are not actively looking for work are called economy inactive (Elder, 2015).

Based on Figure 2, it is obtained that NEET youth in 2017 and 2018 are dominated by inactive youth. In 2017 there were 66.19 percent of NEET youth who were not actively looking for work and 33.81 percent of unemployed youth or actively looking for work. Similar conditions occur in 2018. In 2018 there were 69.29 percent of NEET youth who were not actively looking for work and as many as 30.71 percent of NEET youth were actively looking for work. This is in line with Susanli (2016) who conducted research using 2004-2013 data and found that NEET youth in Turkey are dominated by economically inactive youth. And Byoung-hoon \& Jong-sung (2012) found an inactive youth population was much higher compared to youth unemployment in Korea in 1990-2010. NEET youth inactivity in the labor market can be caused by the youth's desperation to get a job. Despair is seen as a result of difficulty on getting a job. This fact implies a mismatch of supply and demand in the labor market. 


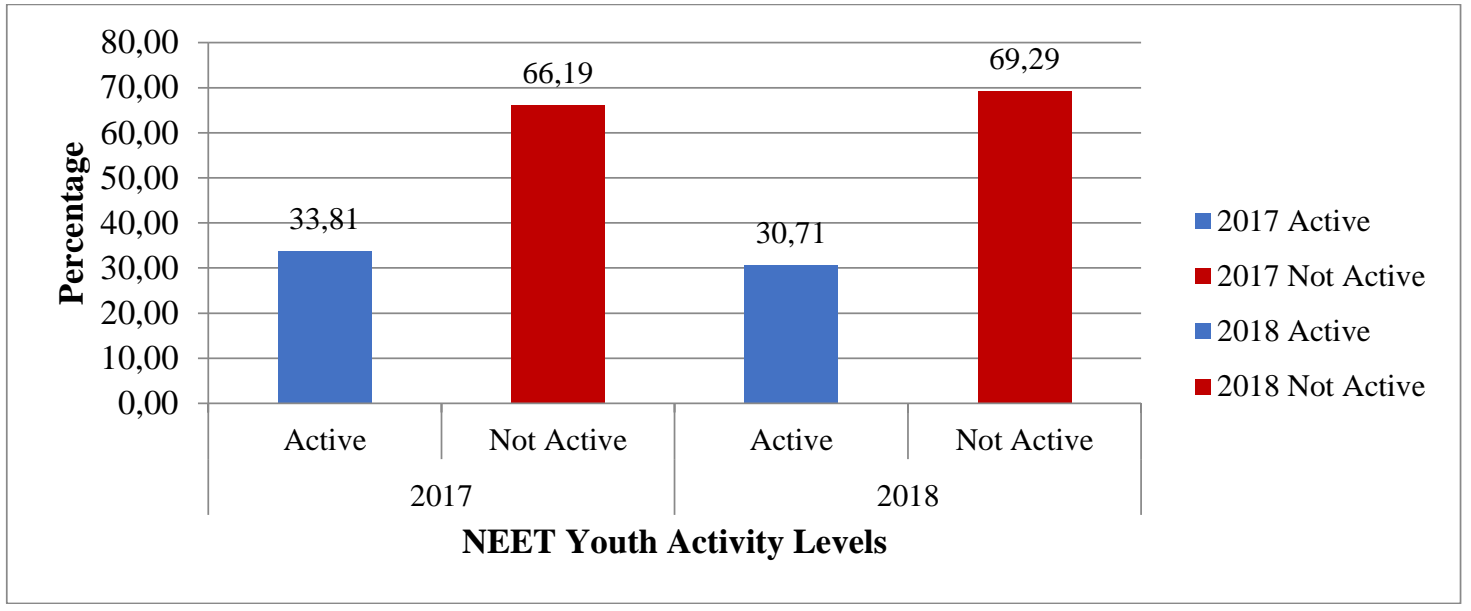

Figure 2.NEET youth activity levels in West Sumatera Province in 2017 and 2018

\section{Determinant characteristics of youth opportunities to become NEET}

The NEET youth characteristic discussed in this study consist of regional classification, youth gender, youth marital status, youth education level, marital status of household head and education level of household head. Figure 3 shows the proportion of NEET youth samples according to their characteristics.

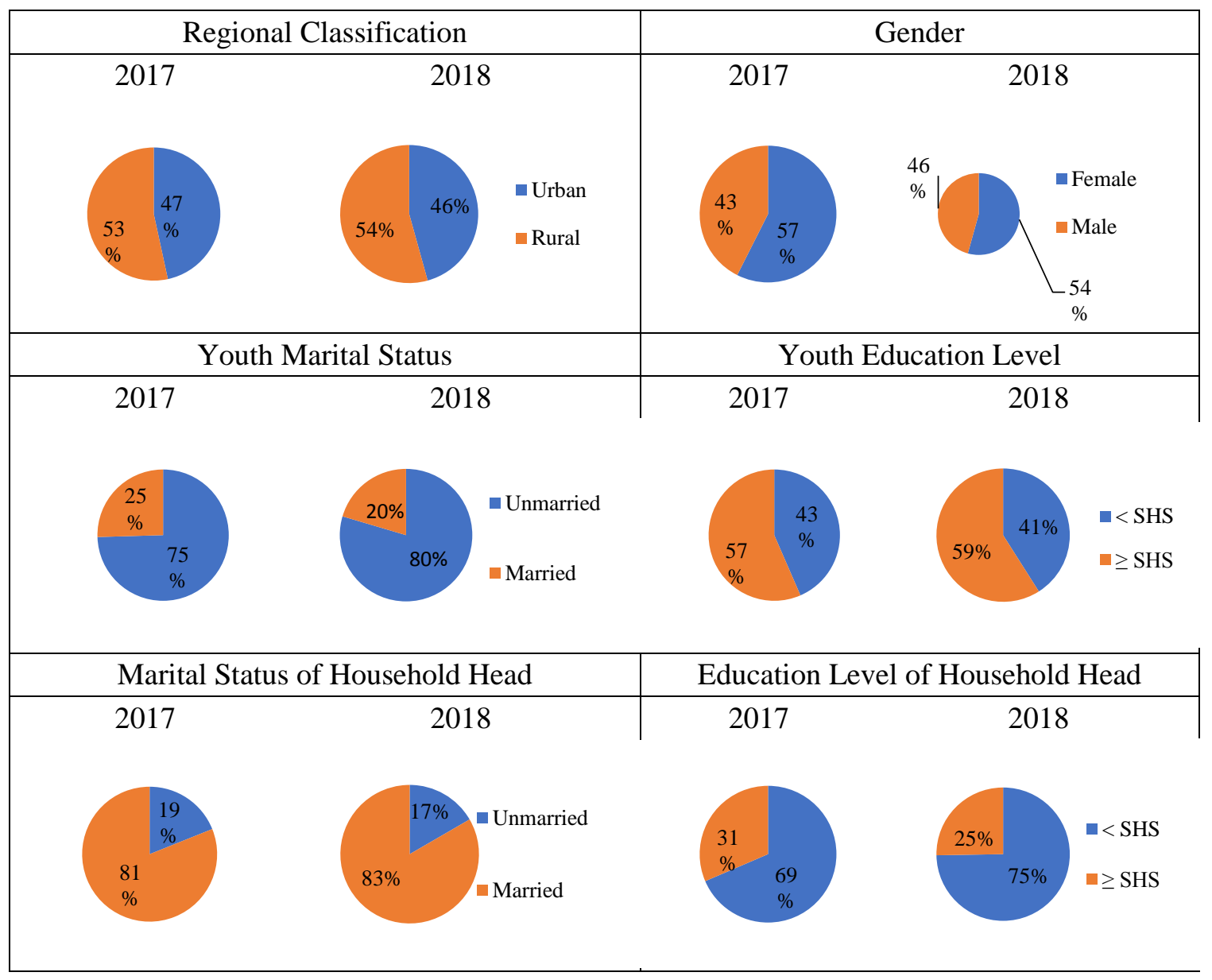

Figure 3. NEET youth characteristics in West Sumatera Province in 2017 and 2018 
NEET youth spread almost evenly in rural and urban areas. However, the proportion of NEET youth living in rural areas is more than NEET youth living in urban areas. Meanwhile, NEET youth in the West Sumatera are more dominated by young women, this is similar to the report of Understanding Children's Work (2013) which states that the NEET youth in Indonesia and Brazil are dominated by young women. Based on marital status, the majority of NEET youths are single. In addition, it was found that the most NEET youths had a minimum of high school education. Viewed from background of the household head, NEET youth is dominated by parents who are married and have a relatively low education.

By using logistic regression analysis, there are two models of research result for 2017 and 2018. Namely the logistic regression model with all independent variables (model 1) and the logistic regression model by put out gender variable (model 2). Based on Table 1, model 1 in 2017 and 2018 do not fulfill all the eligibility requirements of the model in the test that applies in logistic regression. In the Goodness of Fit test, the significance values of Hosmer-Lemeshow test are 0.006 and 0.007 for 2017 and 2018 respectively. These values are smaller than $\alpha$, either at $1 \%$ or $5 \%$ level. So the test result gives the conclusion that the models with all independent variables are not enough to be able to explain the data. Whereas the models that do not contain gender variable already fulfill all the tests in logistic regression. The significance value of G-test show that the models feasible and show that there are effect of the independent variables on the dependent variable. Meanwhile Wald-test result obtained several independent variables that have significant effect on the models. And finally, the result of the HosmerLemeshow test give result that the 2017 model is able to explain data at $1 \%$ real level and the 2018 model is able to explain data at $5 \%$ real level.

Table 1. Logistic regression results

\begin{tabular}{|c|c|c|c|c|}
\hline \multirow[b]{2}{*}{ Variables } & \multicolumn{2}{|c|}{2017} & \multicolumn{2}{|c|}{2018} \\
\hline & $\begin{array}{c}\text { Odds Ratio } \\
\text { Model } 1\end{array}$ & $\begin{array}{c}\text { Odds Ratio } \\
\text { Model } 2\end{array}$ & $\begin{array}{c}\text { Odds Ratio } \\
\text { Model } 1\end{array}$ & $\begin{array}{c}\text { Odds Ratio } \\
\text { Model } 2\end{array}$ \\
\hline Constant & $0.112^{* * * *}$ & $0.102^{* * *}$ & $0.110^{* * * *}$ & $0.101^{* * * *}$ \\
\hline Reg & $\begin{array}{r}1.149 \\
(0.019)\end{array}$ & $\begin{array}{r}1.150 \\
(0.019)\end{array}$ & $\begin{array}{c}1.244^{* *} \\
(0.028)\end{array}$ & $\begin{array}{c}1.243^{* *} \\
(0.028)\end{array}$ \\
\hline Gend & $\begin{array}{r}0.849 \\
(-0.022)\end{array}$ & - & $\begin{array}{r}0.861 \\
(-0.020)\end{array}$ & \\
\hline Mar & $\begin{array}{l}4.776^{* * *} \\
(0.300)\end{array}$ & $\begin{array}{l}5.020^{* * *} \\
(0.313)\end{array}$ & $\begin{array}{c}3.918^{* * *} \\
(0.250)\end{array}$ & $\begin{array}{l}4.099^{* * *} \\
(0.260)\end{array}$ \\
\hline Edu & $\begin{array}{l}2.760^{* * * *} \\
(0.151)\end{array}$ & $\begin{array}{l}2.813^{* * *} \\
(0.155)\end{array}$ & $\begin{array}{l}3.424^{* * *} \\
(0.181)\end{array}$ & $\begin{array}{l}3.463^{\text {*** }} \\
(0.183)\end{array}$ \\
\hline Mar_HH & $\begin{array}{r}1.200 \\
(0.024)\end{array}$ & $\begin{array}{r}1.197 \\
(0.024)\end{array}$ & $\begin{array}{r}1.155 \\
(0.018)\end{array}$ & $\begin{array}{r}1.154 \\
(0.018)\end{array}$ \\
\hline Edu_HH & $\begin{array}{c}0.739^{* * *} \\
(-0.040)\end{array}$ & $\begin{array}{c}0.737^{* * *} \\
(-0.041)\end{array}$ & $\begin{array}{c}0.557^{* * *} \\
(-0.072)\end{array}$ & $\begin{array}{r}0.556^{\text {*** }} \\
(-0.072)\end{array}$ \\
\hline G-Test & 0.000 & 0.000 & 0.000 & 0.000 \\
\hline Hosmer-Lemeshow Test & 0.006 & 0.012 & 0.007 & 0.059 \\
\hline Classification Table Value & 81.3 & 81.3 & 81.7 & 81.8 \\
\hline Pseudo R-Square & 0.138 & 0.137 & 0.146 & 0.145 \\
\hline
\end{tabular}

Source : 2017 and 2018 Sakernas Data (Processed)

Note : Marginal effect in parentheses

****** significant at $1 \% ; 5 \%$

The suitability of the model in predicting a youth's opportunity of being NEET can be seen through classification table value. The classification table values in 2017 and 2018 are above 80 percent. This means, the model has a fairly good ability to 
predict the conditions that occur. Meanwhile, the Pseudo R-Square value is at 13.7 percent in 2017 and 14.5 percent in 2018. This value indicates the ability of independent variable to explain the dependent variable in the model while the rest is explained by other factors outside the model. Table 1 presents the odds ratio and marginal effect of each independent variable in the NEET youth logistic regression models in 2017 and 2018 . For the coefficient $(\beta)$ and standard error (SE) values can be seen in Appendix.

The regional classification only has significant effect on the NEET youth model in 2018. The odds ratio shows the tendency of a youth living in a rural area to be NEET of 1.243 times compared to a youth living in an urban area. This means that youth who live in rural areas have greater opportunities to become NEET youth. These findings confirm Susanli (2016) who states that youth who live in rural areas are more liable to NEET. But contrary to result of research by Elfindri, Soebiakto, Harizal, \& Rezki (2015) who found that youth who live in urban areas actually have greater chance of becoming unemployed or inactive youth. These different findings can be caused by different regional and population conditions. In West Sumatera, the economy and education facilities in rural areas tend to be lower than urban areas, so that young people will have difficulty getting work or continuing education. In the end it will open up opportunities to NEET.

Gender does not influence the determination of NEET youth status. So by excluding the sex factor, model 2 is obtained which is more feasible and fulfills all test in logistic regression. However, based on models 1 of 2017 and 2018, there is tendency for male youth to reduce their chances of becoming NEET youth. This finding shows similarities with the results of Drakaki, Papadakis, Kyridis, \& Papargyris (2014), Elfindri Soebiakto, Harizal, \& Rezki (2015), Susanli (2016) and Alimkhanova (2018) studies that mention young women as being more vulnerable to entering NEET status. This happens because women especially for married women tend to be more easily involved in activities that are not in the labor market such as household activities. Specifically for the West Sumatera province, the matrilineal system puts women in charge of economic resources within their tribes, making it possible for women to just wait at home without playing an active role in the labor market. This happens because they feel secure in the economy.

Marital status is one of the significant factors affect a youth's chances of becoming NEET. Young people who are married have a greater chance of holding NEET status. In 2017 the number of NEET youth will increase by 31.3 percent for every 1 percent increase in young people with married status. Meanwhile in 2018 the number of NEET youths will increase by 26 percent for every 1 percent increase in married status. Although the findings in the study are not in line with the research of Drakaki, Papadakis, Kyridis, \& Papargyris (2014) who found that most of the NEET youth consisted of youth with unmarried status. However, this finding confirms Susanli (2016) study which found that married youth had a greater chance of becoming NEET, especially among young women.

Previous research by Drakaki, Papadakis, Kyridis, \& Papargyris (2014), Inui, Sano, \& Hiratsuka (2015) and Susanli (2016) found that the higher the youth education level, the less likely to become NEET. The results of this study actually show the opposite of previous studies were someone with a high education level has a greater chance of falling into NEET status. In 2017 it was found that the opportunity for someone with a high school education an above was 2.813 times compared to youth who had a level of education bellow high school to enter the NEET group. Likewise for 2018, the opportunity increased to 3.463 times for youth with tertiary education to become NEET youth. This fact shows that difficulty for highly educated youth to find work that suits their educational background. In other words, there is a mismatch 
between the types of labor demand and supply in labor market. This is in line with the research of Byoung-hoon \& Jong-sung (2012) who discovered the phenomenon that young people who do not work in Korea mostly have a high educational background, they tend to be less active in looking for work and prefer to take part in job training because of difficulties in finding work.

The marital status of household head does not have significant effect on the opportunity of a youth becoming NEET. However, the findings show the tendency of youth who have a household head with married status will have a greater chance of becoming NEET. This finding is different from the result of research by Inui, Sano, \& Hiratsuka (2015) who found that a family background such as divorce from parents would encourage the child or youth fall into NEET status.

The education level of household head gives a significant and negative effect on NEET youth opportunities. By 2018, the number of NEET youth in West Sumatera will tend to decrease by 7.2 percent with every 1 percent increase in the number of youth who have household heads with senior secondary education or above. In other words, the proportion of a youth to be NEET will be smaller if he has a household heads with an increasingly high education level. This findings confirm several previous studies namely Byoung-hoon \& Jong-sung (2012) and Alfieri, Sironi, Marta, Rosina\& Marzana (2015) which show that the higher the education of parents, will reduce the risk of the child to enter into NEET status. This is possible because high parental education will be related to economic status and parental education awareness. So they can provide support in order to their children get good education and employment.

\section{CONCLUSIONS AND RECOMMENDATIONS}

\section{Conclusions}

The proportion of NEET youth in West Sumatera province in 2017 ranged from 11.17 percent to 28.04 percent, and increased in 2018 from 11.32 percent to 30.60 percent. There is variation in the proportion of NEET youth between districts and municipalities. In general the proportion of NEET youth in the district is higher than in the municipality area. This can occur because of the economic level, the availability of infrastructure and educational facilities are still limited in the regency. Thus resulting in the difficulty of youth to get a job or continue education.

NEET youth was dominated by youth who were not active in the economy. Only one third of NEET youth are actively looking for work. Then, youth who live in rural areas have a greater chance of becoming NEET compared to youth who live in urban areas. Meanwhile, young people who are married will easily enter NEET status. This relates to young women who prioritize household activities when they are married. The findings differ from most studies precisely on the characteristics of education level. It was found that the higher the youth education level then the chances of youth to be NEET will be higher too. This confirms the phenomenon of higher educated unemployment in recent years. Next, youth who have a household head with higher education will have a smaller opportunity to become NEET youth.

Gender characteristics do not have a significant influence on the determinants of youth status in areas that adhere to this matrilineal kinship system. Nevertheless, the result of the study indicated a tendency for young women to have a greater chance of becoming NEET youth. Women who get the privilege as holder of inheritance actually fall asleep with the comfort they get. With this convenience, women in Minangkabau prefer to play their roles as mother and women in the household rather than enter the labor market. However, the matrilineal kinship system also recognizes women's rights to enter the public sphere. 


\section{Recommendations}

Government effort to reduce the proportion of NEET youth as contained in Sustainable Development Goals (SDGs) must be supported by relevant parties an element of society. In an effort to reduce the proportion of NEET youth in West Sumatera based on the result of this research, the government shall implement policies related to equitable development between urban and rural areas. Equity is considered necessary because with the increase in the economy and public facilities in rural areas then job opportunities, education and the standard of living of the people will also increase.

The result of the research show that the higher the education level, the chance for a young person to become NEET will increase. This means that there is a relatively large proportion of educated inactivity and unemployment. This phenomenon can occur due to the mismatch of background knowledge and skills of youth with available jobs and individual youth factors in the form of laziness and despair. For this reason, the government can take policy to improve the education system by incorporating skills and practices in tertiary education, so that after graduating youth will not feel strange to entering working world. Besides that, the government could create training and skills programs for young people especially young people who are married and not doing economic activities. The purpose of the training is to increase creativity and teach young people skills such as workshop, sewing skills, food industry and so on. Thus fostering the interest and motivation of youth to carry out productive activities and support the family economy.

Regarding methodology, this research uses relatively limited data related to variable coverage. And this relates to availability of data. We suggest that further research on NEET youth could be expended by adding income factors and health indicator as determinant of NEET status. Addition of these two factors will make the result of research more varied with broader scope. Moreover to these factors, we also suggest using personal information from NEET youth related to mental, emotional and psychological of NEET youth. Data like this are usually not available in large-scale surveys, but through direct interviews. Research conducted by direct interviews and using different method will provide other interesting results that are different from this study.

\section{REFERENCES}

Alfieri, S., Sironi, E., Marta, E., Rosina, A., \& Marzana, D. (2015). Young Italian NEETs ( Not in Employment, Education, or Training ) and the Influence of Their Family Background. Europe's Journal of Psychology, 11(2), 311-322. https://doi.org/10.5964/ejop.v11i2.901

Alimkhanova, D. (2018). Understanding the Rising NEET Phenomenon in Southern Khazakhstan. Central Asia Program Fellows Paper, 206, 1-18.

BPS. (2016). Potret Awal Tujuan Pembangunan Berkelanjutan ( Sustainable Development Goals ) di Indonesia. Jakarta: BPS

BPS. (2012). Analisis Statistik Sosial Bonus Demografi dan Pertumbuhan Ekonomi. Jakarta: BPS

BPS. (2017). Pedoman Pencacah Sakernas Februari 2017. Jakarta: BPS

BPS. (2019). Statistik Indonesia 2019. Jakarta: BPS

Bălan, M. (2016). Economic and Social Consequences Triggered By The Neet Youth. Knowledge Horizons-Economics, 8(2), 80-87.

Becker, G. S. (1994). Human Capital: A Theoritical and Empirical Analysis with Special Reference to Education (Third Edition). Chicago: The University of Chicago Press 
Byoung-hoon, L., \& Jong-sung, K. (2012). A Causal Analysis of Youth Inactiveness in the Korean Labor Market. Korea Jurnal, 52(4), 139-165. https://doi.org/10.25024/kj.2012.52.4.139

Crismaru, M., Gagauz, O., \& Buciuceanu-Vrabie, M. (2017). Inclusion of YouthNot In Employment, Education or Training (NEET Youth). Report of UNDP in the Republic of Moldova. Chisinau.

Drakaki, M., Papadakis, N., Kyridis, A., \& Papargyris, A. (2014). Who's The Greek Neet? Neets ' Profile in Greece : Parameters, Trends and Common Characteristics of a Heterogeneous Group. International Journal of Humanities and Social Science, 4(6), 240-254.

Elder, S. (2015). What does NEETs Mean and Why is The concept So Easily Misinterpreted?. Geneva: ILO

Elfindri, Soebiakto, B., Harizal, \& Rezki, J. F. (2015). Youth idleness in Indonesia. Asian Social Science, 11(13), 251-259. https://doi.org/10.5539/ass.v11n13p251

Furlong, A. (2006). Not a Very NEET Solution: Representing Problematic Labour Market Transitions Among Early School-Leavers. Work, Employmeny and Society, 20(3), 553-569. https://doi.org/10.1177/0950017006067001

Hakimi, I. D. R P. (1976). Pegangan Bundo Kanduang di Minangkabau. Bandung: CV. Rosda

Hosmer, D.W. \& Lemeshow, S. (1989). Applied Logistic Regression. USA: A WileyInterscience Publication

International Labour Organization. (2017). Laporan Ketenagakerjaan Indonesia 2017 Memanfaatkan Teknologi untuk Pertumbuhan dan Penciptaan Lapangan Kerja. Kantor Jakarta: ILO

Inui, A., Sano, M., \& Hiratsuka, M. (2015). Precarious Youth and Its Social/Political Discourse: Freeters, NEETs, and Unemployed Youth in Japan. (Comparative Studies on NEET, Freeter, and Unemployed Youth in Japan and the UK), 73-100.

Lee, J. (2018). Human Capital Development for Sustained and Innovative Growth - The Korean Experience and its Implication for Late-comers. The 8th International Forum on Economic Development. Bali-Indonesia.

Maryati, S. (2015). Dinamika Pengangguran Terdidik: Tantangan Menuju Bonus Demografi di Indonesia. Journal of Economic and Economic Education, 3(2), 124136.

Mincer, J. A. (1974). Schooling, Experience and Earnings. New York: National Bureau of Economic Research

Schultz, T. W. (1961). Investment In Human Capital. The American Economic Review, 51(1), 1-17.

Siregar, R. (2017). Sumber Daya Manusia Dalam Pembangunan Nasional. Prosiding Seminar Nasional Tahunan Ilmu Sosial Universitas Negeri Medan, (2), 378-381.

Statistics Canada. (2018). The Transition From School to Work - the NEET ( not in employment, education or training ) Indicator for 15 to 19 Year Olds in Canada. Catallogue no. 81-559-X-No.12. Canada: Statistics Canada

Susanli, Z. B. (2016). Understanding The Neet in Turkey. Eurasian Journal of Economics and Finance, 4(2), 42-57. https://doi.org/10.15604/ejef.2016.04.02.004

Understanding Children's Work. (2013). NEET Youth Dynamics in Indonesia and Brazil: A Cohort Analysis. Understanding Children's Work (UCW) Programme Working Paper Series. Rome:UCW

Young Women's Trust. (2014). Literature Review Neets and Gender. London: Young Women's Trust 


\section{APPENDIX}

Table 2. Logistic regression variables

\begin{tabular}{lcl}
\hline Variables & Categories \\
\hline Youth Aged 15-24 Years Old $(\mathrm{Y})$ & 1 & $:$ NEET Youth \\
& 0 & $:$ Not a NEET Youth \\
Regional Classification $\left(\mathrm{X}_{1}\right)$ & 1 & $:$ Rural \\
& 0 & $:$ Urban \\
Youth Gender $\left(\mathrm{X}_{2}\right)$ & 1 & $:$ Male \\
& 0 & $:$ Female \\
Youth Marital Status $\left(\mathrm{X}_{3}\right)$ & 1 & $:$ Married \\
& 0 & $:$ Unmarried \\
Youth Education Level $\left(\mathrm{X}_{4}\right)$ & 1 & $: \geq$ Senior High School (SHS) \\
& 0 & $:$ Senior High School (SHS) \\
Marital Status of Household Head $\left(\mathrm{X}_{5}\right)$ & 1 & $:$ Married \\
& 0 & $:$ Unmarried \\
Education Level of Household Head $\left(\mathrm{X}_{6}\right)$ & 1 & $: \geq$ Senior High School (SHS) \\
& 0 & $:$ S Senior High School (SHS) \\
\hline
\end{tabular}

Table 3.The proportion of NEET youth samples by regency or municipality in West Sumatera in 2017 and 2018

\begin{tabular}{cllc}
\hline \multirow{2}{*}{ No } & \multirow{2}{*}{ Name of Regency or Municipality } & \multicolumn{2}{c}{ The proportion of NEET Youth (\%) } \\
\cline { 3 - 4 } & & 2017 & 2018 \\
\hline Regency & & 14.19 & 12.90 \\
1 & Kep. Mentawai & 17.58 & 21.14 \\
2 & Pesisir Selatan & 20.70 & 21.13 \\
3 & Solok & 21.60 & 23.03 \\
4 & Sijunjung & 12.25 & 14.89 \\
5 & Tanah Datar & 19.64 & 17.67 \\
6 & Padang Pariaman & 15.93 & 13.66 \\
7 & Agam & 19.58 & 19.21 \\
8 & Lima Puluh Kota & 28.04 & 30.60 \\
9 & Pasaman & 25.84 & 16.67 \\
10 & Solok Selatan & 20.28 & 20.94 \\
11 & Dharmasraya & 21.40 & 23.08 \\
12 & Pasaman Barat & & \\
Municipality & & 18.10 & 15.70 \\
1 & Padang & 17.32 & 17.16 \\
2 & Solok & 17.76 & 18.84 \\
3 & Sawahlunto & 22.45 & 14.29 \\
4 & Padang Panjang & 11.17 & 11.32 \\
5 & Bukittinggi & 12.82 & 11.86 \\
6 & Payakumbuh & 15.76 & 14.04 \\
7 & Pariaman & 18.27 & 20.28 \\
\hline
\end{tabular}

Source : 2017 and 2018 Sakernas Data (Processed) 
Table 4. The constant and coefficients $(\beta)$ and standard error (SE) values of logistic regression result in 2017 and 2018

\begin{tabular}{|c|c|c|c|c|c|c|c|c|}
\hline \multirow{3}{*}{ Variables } & \multicolumn{4}{|c|}{2017} & \multicolumn{4}{|c|}{2018} \\
\hline & \multicolumn{2}{|c|}{ Model 1} & \multicolumn{2}{|c|}{ Model 2} & \multicolumn{2}{|c|}{ Model 1} & \multicolumn{2}{|c|}{ Model 2} \\
\hline & $\mathrm{B}$ & $\mathrm{SE}$ & $\beta$ & $\mathrm{SE}$ & $\mathrm{B}$ & $\mathrm{SE}$ & $\beta$ & $\mathrm{SE}$ \\
\hline Constant & $-2.187 * * *$ & 0.128 & $-2.280 * * *$ & 0.118 & $-2.207 * * *$ & 0.147 & $-2.292 * * *$ & 0.138 \\
\hline Reg & 0.139 & 0.087 & 0.140 & 0.087 & $0.218 * *$ & 0.094 & $0.217 * *$ & 0.094 \\
\hline Gend & -0.163 & 0.087 & - & - & -0.150 & 0.093 & - & - \\
\hline Mar & $1.564 * * *$ & 0.116 & $1.613^{* * * *}$ & 0.113 & $1.366^{* * * *}$ & 0.135 & $1.411^{* * *} *$ & 0.132 \\
\hline Edu & $1.015^{* * * *}$ & 0.086 & $1.034 * * *$ & 0.086 & $1.231 * * *$ & 0.093 & $1.242 * * *$ & 0.093 \\
\hline Mar_HH & 0.182 & 0.107 & 0.180 & 0.107 & 0.144 & 0.121 & 0.143 & 0.121 \\
\hline Edu_HH & $-0.303^{* * *}$ & 0.093 & $-0.306^{* * *}$ & 0.093 & $-0.585^{* * *}$ & 0.105 & $-0.586^{* * *}$ & 0.105 \\
\hline
\end{tabular}

Source : 2017 and 2018 Sakernas Data (Processed)

Note : Marginal effect in parentheses

****** significant at $1 \% ; 5 \%$ article distributed under the terms and conditions of the Creative Commons Attribution (CC BY) license (http://creativecommons.org/licenses/by/4.0/). 